\title{
A miRNA signature associated with human metastatic medullary thyroid carcinoma
}

\author{
Libero Santarpia ${ }^{1, *}$, George A Calin ${ }^{2}$, Liana Adam ${ }^{3}$, Lei Ye', Alfredo Fusco ${ }^{4}$, \\ Serena Giunti ${ }^{5}$, Christina Thaller ${ }^{6}$, Laura Paladini ${ }^{7}$, Xinna Zhang ${ }^{8}$, Camilo Jimenez', \\ Francesco Trimarchi $^{9}$, Adel K El-Naggar ${ }^{10}$ and Robert F Gagel ${ }^{1,11}$
}

Departments of ${ }^{1}$ Endocrine Neoplasia and Hormonal Disorders ${ }^{2}$ Experimental Therapeutics ${ }^{3}$ Urology, The University of Texas M.D. Anderson Cancer Center, Houston, Texas, USA

${ }^{4}$ Department of Oncology, The University of Naples, Naples, Italy

${ }^{5}$ Department of Pathology, Centro Oncologico Fiorentino, Sesto Fiorentino, Florence, Italy

${ }^{6}$ Verna and Marrs McLean Department of Biochemistry and Molecular Biology Baylor College of Medicine, Houston Texas, USA

${ }^{7}$ Department of Oncology, Istituto Toscano Tumori, Hospital of Prato, Prato, Italy

${ }^{8}$ Department of Gynecologic Oncology, Center for RNA Interference and Non-coding RNAs, The University of Texas MD Anderson Cancer Center, Houston, Texas, USA

${ }^{9}$ Department of Endocrinology, University of Messina, Messina, Italy

${ }^{10}$ Department of Pathology, The University of Texas M.D. Anderson Cancer Center, Houston, Texas, USA

${ }^{11}$ Department of Internal Medicine, The University of Texas M.D. Anderson Cancer Center, Houston, Texas, USA

*L Santarpia is now at Translational Research Unit, Department of Oncology, Istituto Toscano Tumori,

Prato and Florence, Italy

Correspondence should be addressed to L Santarpia or R F Gagel Email

liberosantarpia@yahoo.it or rgagel@mdanderson.org

\begin{abstract}
MicroRNAs (miRNAs) represent a class of small, non-coding RNAs that control gene expression by targeting mRNA and triggering either translational repression or RNA degradation. The objective of our study was to evaluate the involvement of miRNAs in human medullary thyroid carcinoma (MTC) and to identify the markers of metastatic cells and aggressive tumour behaviour. Using matched primary and metastatic tumour samples, we identified a subset of miRNAs aberrantly regulated in metastatic MTC. Deregulated miRNAs were confirmed by quantitative real-time PCR and validated by in situ hybridisation on a large independent set of primary and metastatic MTC samples. Our results uncovered ten miRNAs that were significantly expressed and deregulated in metastatic tumours: miR-10a, miR-200b/-200c, miR-7 and miR-29c were down-regulated and miR-130a, miR-138, miR-193a-3p, miR-373 and miR-498 were up-regulated. Bioinformatic approaches revealed potential miRNA targets and signals involved in metastatic MTC pathways. Migration, proliferation and invasion assays were performed in cell lines treated with miR-200 antagomirs to ascertain a direct role for this miRNA in MTC tumourigenesis. We show that the members of miR-200 family regulate the expression of E-cadherin by directly targeting ZEB1 and ZEB2 mRNA and through the enhanced expression of tumour growth factor $\beta$ (TGF $\beta)-2$ and TGF $\beta-1$. Overall, the treated cells shifted to a mesenchymal phenotype, thereby acquiring an aggressive phenotype with increased motility and invasion. Our data identify a robust miRNA signature associated with metastatic MTC and distinct biological processes, e.g., TGF $\beta$ signalling pathway, providing new potential insights into the mechanisms of MTC metastasis.
\end{abstract}

\footnotetext{
Key Words

- miRNA

- medullary thyroid carcinoma

- miR-200

- metastasis

- signature

- cadherins

- ZEBs

- tumour growth factor- $\beta$

- cellular functions

- signal transduction pathways
}

Endocrine-Related Cancer (2013) 20, 809-823 http://erc.endocrinology-journals.org DOI: 10.1530/ERC-13-0357
(C) 2013 Society for Endocrinology Printed in Great Britain
Published by Bioscientifica Ltd 


\section{Introduction}

Medullary thyroid carcinoma (MTC) is a neuroendocrine tumour thought to originate from neural crest parafollicular C-cells. Approximately $25 \%$ of MTC cases occur in the context of autosomal dominant multiple endocrine neoplasia syndrome type 2 (MEN2), MEN2A and MEN2B and familial MTC due to RET proto-oncogene germline mutations (Hofstra et al. 1994, Santoro et al. 1995, Eng et al. 1996, American Thyroid Association Guidelines Task Force et al. 2009). In hereditary MTC, a genetic diagnosis provides an opportunity for a prophylactic thyroidectomy and cancer cure. However, most cases of MTC are sporadic, presenting with metastatic disease at diagnosis, both in the local and in the regional lymph nodes, and in distant organs, especially in the lungs, liver and bones. While MTC is typically a slow-growing tumour, $40-50 \%$ of patients with metastatic disease have a 5-year overall survival rate. Nearly, all patients ultimately succumb to the disease (Hofstra et al. 1996). RET mutations are necessary but not sufficient for MTC tumourigenesis, and further molecular events (e.g. allelic imbalances between mutant and WT RET) are required for the development of MTC (Koch et al. 2001). The role of RET in MTC progression is still not well clarified, and in the metastatic context, RET has been demonstrated to cooperate with different signalling transduction pathways (Santarpia \& Bottai 2013). However, tumour metastasis is a complex multistep process involving several types of alterations in cell adhesion, migration, survival, lymph/angiogenesis and proteolysis, which can ultimately lead to apoptosis, immune escape and homing to target organs. As a consequence, the expression profiles of specific genes involved in the control of the aforementioned functions and intracellular signal transducers are coordinately modified. The cascade of events that leads to metastasis in thyroid cancer, especially MTC, is still poorly understood. MicroRNAs (miRNAs), a class of non-coding RNA, have been shown to regulate gene expression through specific binding to complementary mRNA target sequences, typically in their $3^{\prime}$-untranslated regulatory regions, which results in the degradation of target mRNAs and/or the inhibition of the translational process (Lujambio \& Lowe 2012). A possible role for miRNAs in tumourigenesis may be to function as tumour promoters or tumour suppressors by regulating multiple cellular processes, specifically targeting the genes involved in cancer cell biology (Santarpia et al. 2010, Iorio \& Croce 2012). Indeed, increasing evidence supports the important role of miRNAs in almost all types of cancers, including thyroid cancer reviewed in Visone et al. (2007), Pallante et al. (2010), and Iorio \& Croce (2012), although there is increasing evidence that supports an important and generalised role for miRNAs in mediating tumour metastasis (Santarpia et al. 2010, Valastyan \& Weinberg 2011).

In this study, we identified a robust miRNA signature associated with MTC metastases. Analysis of a subset of these miRNAs confirmed their role in the pathobiology and progression of MTC, providing new insights into the complex mechanisms involved in the metastatic process of this tumour. In particular, the down-regulation of the miR-200 family in MTC cells, which endogenously express high levels of these miRNAs, hinders the epithelial to mesenchymal transition (EMT), by down-regulating E-cadherin expression. miR-200 down-regulation can cause an increase in tumour growth factor $\beta$ (TGF $\beta$ )-2 and augmented migration and invasion potential of the tumour cells through the direct targeting of $Z E B 1$ and $Z E B 2$. These results strongly suggest an important role for the miR-200 family in regulating a shift in the MTC cell phenotype during cancer progression.

\section{Subjects and methods}

\section{MTC tumour selection and miRNA expression profiling}

Paired primary tumour and metastatic lymph node tissues were simultaneously obtained from six different sporadic MTC patients to reduce the potential for unrelated sample variability. A total of 12 samples, six primary and six paired metastatic tumours derived from adjacent metastatic lymph nodes, were used for miRNA expression array profiling (discovery data set). An additional 65 wellcharacterised MTC tumour samples, 31 primary and 34 metastatic tumours (validation data set), were obtained for confirmation studies (Supplementary Table 1, see section on supplementary data given at the end of this article). Clinical and pathological features of patients and tumours are reported in Supplementary Table 1. All MTC specimens were pathologically confirmed and further examined by immunostaining using at least two of the following neuroendocrine markers: calcitonin, chromogranin, synaptophysin and carcinoembryonic antigen. All patient samples were collected under an approved institutional board protocol at The University of Texas M.D. Anderson Cancer Center. RNA was extracted using miRVANA (Ambion, Foster City, CA, USA) or Trizol reagent

Published by Bioscientifica Ltd. 
(Invitrogen) as recommended by the manufacturer, with minimal modifications. For array analysis, $720 \mathrm{ng}$ primary/metastasis tumour RNA pairs were labelled with Hy3 and Hy5 fluorescent label using the miRCURY LNA Array power labelling kit (Exiqon, Denmark A/S, Vedback, Denmark), following the procedure described by the manufacturer. The Hy3-labelled samples and a Hy5labelled reference RNA sample were mixed pair-wise and hybridised to the miRCURY LNA array version 10.0 (Exiqon), which contains more than 1200 capture probes covering all human, mouse and rat miRNA sequences annotated and registered in the miRBASE version 12.0 at the Sanger Institute (http://microrna.sanger.ac.uk/ sequences/) and Exiqon miRPlus mature miRNAs. The hybridisation was performed according to the miRCURY LNA array manual using a Tecan HS4800 hybridisation station (Tecan, Grödig, Austria). After hybridisation, the microarray slides were scanned and stored in an ozone-free environment (ozone level below $2.0 \mathrm{ppb}$ ) to prevent potential bleaching of the fluorescent dyes. The LNA array microarray slides were scanned using the Agilent G2565BA Microarray Scanner System (Agilent Technologies, Inc., Santa Clara, CA, USA).

\section{Statistical and bioinformatic analysis of microarray data}

The quantified signals were normalised using the global locally weighted scatterplot smoothing (Lowess) regression algorithm on the background-subtracted data (background corrected Normexp with offset value 10) (Ritchie et al. 2007). Student's $t$-tests or Mann-Whitney $U$ tests were performed to identify various levels of miRNA expression in the primary vs metastatic tumours. The miRNAs with $P<0.05$ were considered to be significant. The miRNA hierarchical clustering analysis was performed using GeneSpring GX version 4.0 (Agilent Technologies, Inc. and Strand Life Sciences Pvt. Ltd., San Francisco, CA, USA). Single channel median corrected signals were scaled to the median values of all known miRNAs, with the threshold set to 1 . The clustering algorithm used a Pearson uncentered distance metric and a complete linkage rule.

\section{Validation of microarray data}

MiRNA quantitative real-time PCR Expression of mature miRNAs was analysed by the TaqMan miRNA Assay (Applied Biosystems) using conditions defined by the manufacturer. Briefly, single-stranded cDNA was synthesised from $5.5 \mathrm{ng}$ total RNA in a $15 \mu \mathrm{l}$ reaction volume using the TaqMan MicroRNA Reverse
Transcription kit (Applied Biosystems). The reactions were first incubated at $16^{\circ} \mathrm{C}$ for $35 \mathrm{~min}$ and then at $42^{\circ} \mathrm{C}$ for $30 \mathrm{~min}$, followed by an inactivation step $\left(85^{\circ} \mathrm{C}\right.$ for $5 \mathrm{~min}$ ). Quantitative PCR amplification of the cDNAs was performed using sequence-specific primers from the TaqMan MicroRNA Assay Human Panel (Applied Biosystems). The $20 \mu \mathrm{l} \mathrm{PCR}$ included $10 \mu \mathrm{l} 2 \times$ Universal PCR Master Mix (no AmpErase UNG), $2 \mu$ of each $10 \times$ TaqMan MicroRNA Assay Mix and $1.5 \mu \mathrm{l}$ RT product with an amplification program of $95^{\circ} \mathrm{C}$ for $9 \mathrm{~min}$, followed by 40 cycles at $95{ }^{\circ} \mathrm{C}$ for $15 \mathrm{~s}$ and $60^{\circ} \mathrm{C}$ for $1 \mathrm{~min}$. The relative expression level was computed using the $2^{-\Delta C t}$ analysis method. To correct for variability among different samples, expression level of a target miRNA was normalized to the expression levels of two different reference genes (as genes found stably expressed across most of the samples), RNU6B (RNU6-6P) and miR-16. The Wilcoxon test was used for statistical analysis. Statistical significance between miRNA expression in the primary and metastatic tumours was set as 0.05 . We performed a further comparison $T$-test analysis analysing the miRNA expressions of sporadic and hereditary tumours. Statistical significance was set at 0.05 .

\section{Tissue microarray and miRNA expression by in situ} hybridisation Standard formalin-fixed paraffinembedded (FFPE) MTC specimens were obtained from archived patient specimens representing the same tumours analysed by qRT-PCR. To generate the tissue microarray, $4 \mu \mathrm{m}$ sections were H\&E stained to identify representative regions for a core biopsy. Three core tissue biopsies were obtained from each tumour specimen representing different areas of the tumours. The presence of tumour tissue within the final arrayed samples was verified by H\&E-staining. For the in situ detection of miRNA expression, $4 \mu \mathrm{m}$ sections of the tissue microarray were deparaffinized in a xylene series and rehydrated through an ethanol series (100-25\%). After performing a proteinase $\mathrm{K}$ digestion $(30 \mu \mathrm{g} / \mathrm{ml}$; Roche Applied Science) for $10 \mathrm{~min}$ and fixation in $4 \%$ paraformaldehyde, slides were prehybridised in hybridisation solution (50\% formamide, $5 \times$ SSC, $500 \mu \mathrm{g} / \mathrm{ml}$ yeast tRNA, $1 \times$ Denhardt's solution) for $1 \mathrm{~h}$ and hybridised overnight with double digoxigenin (DIG)-labelled miRNA-locked nucleic acid probes (Exiqon). After stringent washes (50\% formamide, $2 \times$ SSC) at a specific hybridisation temperature, chromogenic detection of signals was performed using an anti-DIG antibody (Roche, 1:400 dilution) and alkaline phosphatase-conjugated secondary antibody (Ventana) using NBT-BCIP as the substrate according to the manufacturer's instructions. We also used a double-DIG-labelled U6

Published by Bioscientifica Ltd. 
snRNA probe as a positive control (Exiqon). Only the presence of cytoplasmic staining (mature miRNA) in tumour cells was recorded and classified as positive or negative. The sections were evaluated independently by two blinded and experienced pathologists according to the percentage of stained cells, with $<20 \%$ of the cells stained was designated as low expression of miRNA, and more than $20 \%$ of the cells stained was designated as high expression of miRNA. The scores of the two pathologists were compared and any discrepant scores were trained through re-examining the stainings by both pathologists to achieve a consensus score.

Determination of labelling efficiency was performed for each single probe at different serial concentrations. Scramble probes were used as negative controls. MiRNA sequences probes are reported in Supplementary Table 2, see section on supplementary data given at the end of this article.

\section{MTC cell culture}

MTC TT and MZ-CRC-1 (MZ) cell lines, previously characterised by immunocytochemistry, RET gene mutation (Supplementary Figure 1, see section on supplementary data given at the end of this article) and Affymetrix Array SNP6.0 analysis, were grown in F-12K medium (TT) and in DMEM (MZ) supplemented with 10\% foetal bovine serum using standard cell culture methods. Adenoviral vector infection and antagomir transfection efficiencies were tested using a Luciferase assay as described previously (Takahashi et al. 1985). Antagomir probes for miR-200b and miR-200c (Exiqon) were transfected using $10 \mu \mathrm{l}$ Lipofectamine 2000 (Invitrogen, Inc.) and $20 \mathrm{nM}$ mercury LNA probes according to the manufacturer's instructions. Total RNA and protein were isolated at $48-72 \mathrm{~h}$.

\section{Protein expression analysis}

\section{Western blot and confocal immunofluorescence}

Western blot analysis: protein lysates $(40 \mu \mathrm{g})$ were separated on $10-12 \%$ gradient polyacrylamide gels (Bio-Rad) and transferred to PVDF membranes for standard western blot analysis. Antibodies against epithelial and mesenchymal markers included the following: anti-E-cadherin (Cell Signaling Technology, Danvers, MA, USA), anti$\mathrm{N}$-cadherin (BD, Franklin Lakes, NJ, USA), anti- $\beta$-catenin (Millipore, Billerica, MA, USA), anti-vimentin (Abcam, Cambridge, UK), anti-ZEB1/2 (Cell Signaling Technology, Inc.; and Novus Biologicals, Littleton, CO, USA), antiTGFB-1 (Abcam), anti-TGFß-2 (Abcam), anti-TWIST1 (Santa Cruz, Dallas, TX, USA) and anti-SNAI1 and 2 (Abcam).
Antibody interactions were detected by an IR-conjugated anti-mouse antibody using an Odyssey Imaging System and Analysis Software (Li-Cor Bioscience, Lincoln, NE, USA). Normalisations were performed to $\beta$-actin. Confocal immunofluorescence: MTC cells were plated onto Lab-Tek 8-chamber slides (Thermo Scientific, Nunc, NY, USA). Following transfection (48-72 h), immunofluorescence was performed according to Cell Signaling Technology's protocol. Antibodies for $\beta$-catenin (L54E2, Cell Signaling), E-cadherin (Cell Signaling), anti-N-cadherin (Cell Signaling) and fluorochrome-conjugated secondary antibodies were used. Confocal microscopy was performed with an Olympus FV 500 laser confocal IX-71 microscope.

\section{Cell proliferation and matrigel invasion} assays The effect of $m i R-200$ expression on cell proliferation was examined using an Aqueous One Solution Cell Proliferation Assay (Promega), which employs the tetrazolium compound 3-(4,5-dimethylthiazol-2-yl)-5(3-carboxymethoxyphenyl)-2-(4-sulfophenyl)-2H-tetrazolium (MTS). Stably transfected MZ and TT cells were cultured in 96-well plates with the addition of MTS at the indicated periods, followed by absorbance readings at $490 \mathrm{~nm}$ to determine the relative cell viability. The invasion properties of stably transfected MZ and TT cells were examined as described previously using the standard Matrigel trans-well assay (Molina et al. 2010).

Immunohistochemistry assays Immunohistochemistry was performed on $4 \mu \mathrm{m}$ FFPE tumour tissues for TGF $\beta-1$ (Ab28381), TGF $3-2$ (Ab36495), E-cadherin (Ab1416) and vimentin (Ab8069). Positivity for the markers was defined based on staining intensity and tumour cellularity.

\section{Cell adhesion}

Electron microscopy MTC cell line samples were fixed with a solution containing 3\% glutaraldehyde plus $2 \%$ paraformaldehyde in $0.1 \mathrm{M}$ cacodylate buffer, $\mathrm{pH} 7.3$, for $1 \mathrm{~h}$. After fixation, the cells were washed and treated with $0.1 \%$ Millipore-filtered cacodylate-buffered tannic acid, post-fixed with $1 \%$ buffered osmium tetroxide for $30 \mathrm{~min}$ and stained en bloc with $1 \%$ Millipore-filtered uranyl acetate. The samples were dehydrated in increasing concentrations of ethanol, infiltrated and embedded in LX-112 medium (polymerised at $70^{\circ} \mathrm{C}$ for 2 days). Ultrathin sections were cut on a Leica Ultracut microtome (Leica, Deerfield, IL, USA), stained with uranyl acetate and lead citrate in a Leica EM Stainer and examined with a JEM 1010 transmission

Published by Bioscientifica Ltd. 
electron microscope (JEOL, USA, Inc., Peabody, MA, USA) at an accelerating voltage of $80 \mathrm{kV}$. Digital images were obtained using an AMT Imaging System (Advanced Microscopy Techniques Corp., Danvers, MA, USA).

\section{Bioinformatics}

miRNA targets, gene ontology and pathway analysis Initially, three programs, PicTar (http://pictar. mdc-berlin.de/), miRanda (http://www.microrna.org/microrna/home.do) and TargetScan (http://www.targetscan. org/), were used to predict the mRNA targets of the ten
miRNAs. To strengthen our search, we used an additional bioinformatic approach employing the intersections of two or more databases with GOmir software (Roubelakis et al. 2009). GOmir target names were then crossreferenced using DAVID and Entrez Gene (http://www. ncbi.nlm.nih.gov/sites/entrez?db=gene) to obtain Entrez Gene ID numbers. Entrez Gene ID lists were used to perform pathway analysis (DAVID and Ingenuity Pathway analysis). GO analysis was performed using the GO annotations downloaded from http:// geneontology.org/.

A
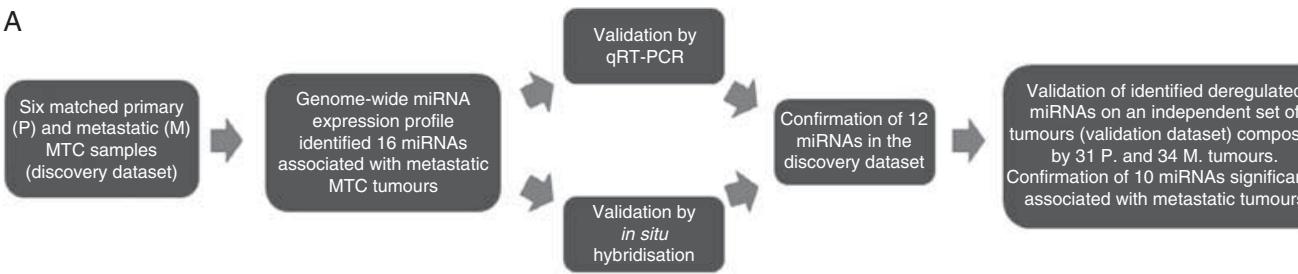
miRNAs on an independent set of mours (validation dataset) composed by $31 \mathrm{P}$. and $34 \mathrm{M}$. tumours.

B

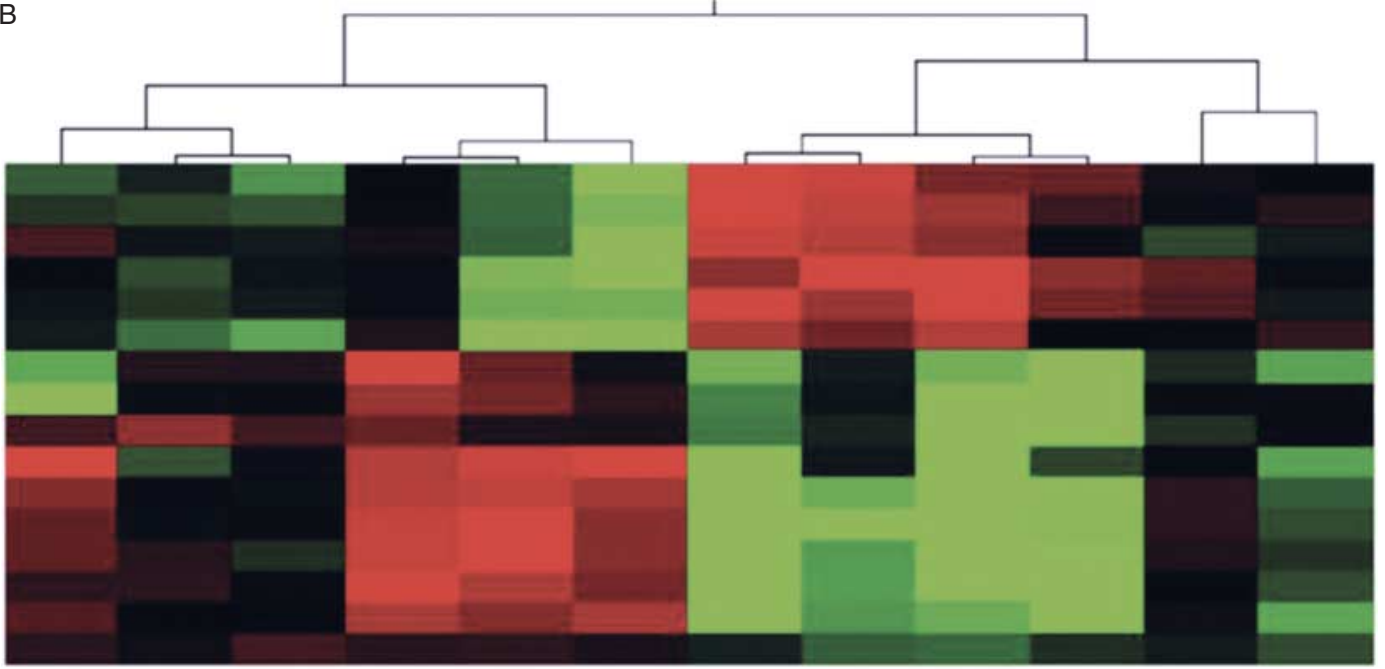

hsa-miR-10a

hsa-miR-7

hsa-miR-129*/129-3p

hsa-200b

hsa-200c

hsa-miR-29c

hsa-miR130a

hsa-miR138

hsa-miR193a-3p

hsa-miR-326

hsa-miR-373

hsa-miR-498

hsa-miR-637

hsa-miR-623

hsa-miR-658

hsa-miR-575

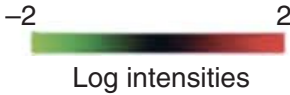

Figure 1

Experimental design and flow chart showing the identification of a metastatic miRNA signature in medullary thyroid carcinoma (A). MiRNA expression profiling of matched primary and metastatic tumour samples (discovery data set). Supervised hierarchical cluster one-minus correlation average for linkage of class prediction, identified 16 significant deregulated miRNAs in metastatic samples (B).

Published by Bioscientifica Ltd. 

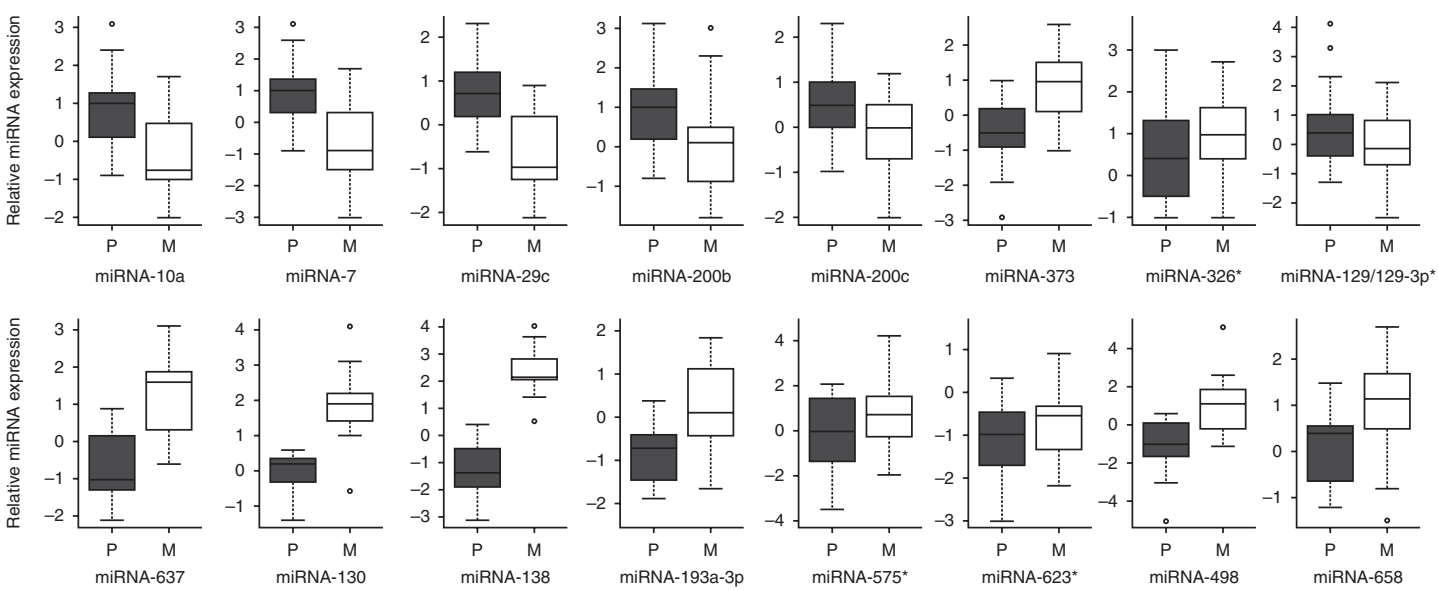

Figure 2

Quantitative real-time PCR analyses on an independent set (validation data set) of primary ( $P$; grey box plots) and metastatic tumours ( $M$; white box plots) demonstrated and confirmed 12 significant miRNA genes associated

\section{Results}

\section{A miRNA expression profile signature of metastatic MTC}

Among several cancer subtypes, MTC represents $2-8 \%$ of thyroid cancer cases. Despite this low frequency, there is a disproportionate number of deaths from MTC compared with other thyroid cancers. Indeed, $50 \%$ of MTC patients with metastatic or recurrent disease have a survival rate of 4 years. To assess the potential role of miRNAs in MTC tumour progression and metastasis, we applied a multistep approach that began with an array expression analysis of paired patient samples (Fig. 1A). We validated the expression of deregulated miRNAs in an independent set of MTC tumours (Supplementary Table 1) and identified a robust miRNA signature associated with metastasis. Furthermore, we confirmed the reliability of our genes by in vitro analysis. It is important to note that unlike many tumours, normal tissue in MTC is not easily available for direct comparison because of the rarity of normal thyroid C-cells. Comparative analysis of the miRNA expression arrays between primary and metastatic MTC samples identified 16 miRNAs with significant $(P<0.05)$ differences greater than twofold (Fig. 1B). Within this group, we found six miRNAs that were selectively down-regulated in metastatic tumours: $m i R-7$, miR-10a, miR-29c, miR-129/129-3p and miR-200b/-200c. Ten miRNAs were found to be up-regulated: $m i R-130 a$, miR-138, miR-193a-3p, miR-326, miR-373, miR-498, miR575, miR-637, miR-623 and miR-658. To validate this miRNA signature, we performed qRT-PCR on an independent sample set (validation data set) (Fig. 2). While miRNA with metastatic tumours. MiR-129/129-3p, miR-326, miR-575 and miR-623 were not significant differentially expressed between the $\mathrm{P}$ and $\mathrm{M}$ groups (asterisks indicate the four miRNAs not statistically significant).

expression almost invariably correlated with the array results, qRT-PCR analysis showed a statistically significant deregulation of only 12 miRNAs (Fig. 2). Four miRNAs (miR-129/129-3p, miR-326, miR-575 and miR-623) were found to be non-significant in the two cohorts of tumour samples (primary and metastatic tumours). Moreover, sporadic and hereditary MTC tumours in the validation data set showed not significant differences in terms of miRNA expressions. In situ hybridisation analysis was performed to confirm cancer cell-specific expression of miRNAs (Fig. 3). An important aspect of our study is that it shows how selected miRNAs are expressed in specific tumour regions or cell types (Fig. 3). The in situ hybridisation confirmed the specificity of only 12 miRNAs for the MTC cancer cells (Fig. 3). Four miRNAs (miR-326, miR-623, miR-637 and miR-658) were not tumour specific. When these four miRNAs are taken together with miR-129/129-3p and miR-575 (excluded by qRT-PCR), six of the original 16 miRNAs were excluded from further analysis. It is noteworthy that specific miRNAs analysed (e.g. $m i R-7$, and $m i R-200 b / c$ ) were also expressed in C-cell hyperplasia (Fig. 3).

\section{The miRNA metastatic signature identifies gene targets involved in metastatic functions}

The miRNA metastatic signature of ten miRNAs identified candidate target genes coupled to cell-to-cell communication, cell adhesion, the EMT, tight gap junctions and extracellular matrix (ECM) interactions (see Supplementary Figure $2 \mathrm{~A}$ and $\mathrm{B}$, see section on supplementary data

Published by Bioscientifica Ltd. 


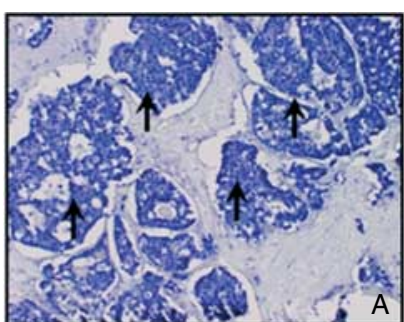

$\operatorname{miR}-7$

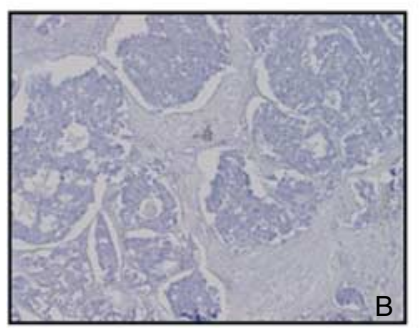

Negative control

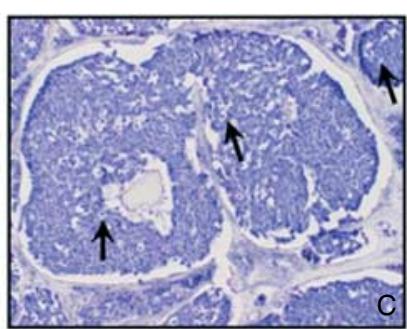

miR-200b

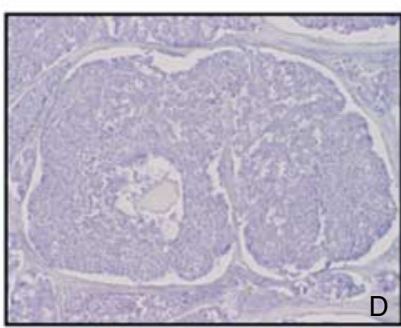

Negative control

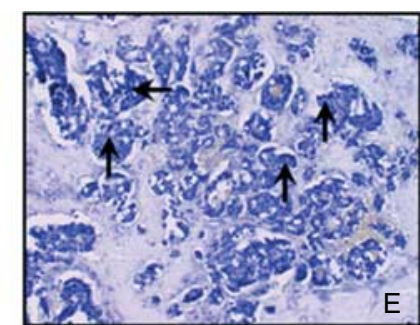

miR-373

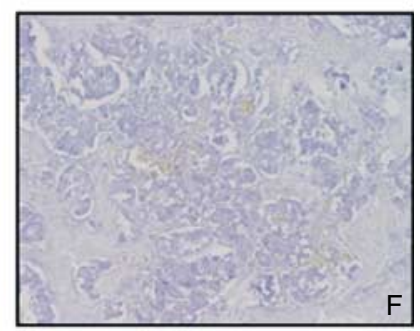

Negative control

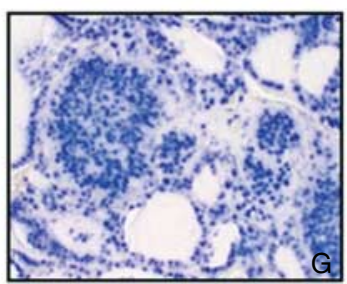

miR-7

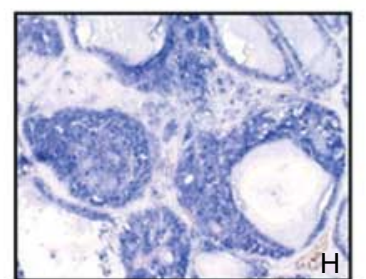

miR-200c

\section{Figure 3}

Detection of miRNA transcripts by in situ hybridisation in medullary thyroid neoplastic cells. In situ hybridisation analyses using double DIG-conjugated, LNA-modified DNA probes complementary to miRNAs were performed on $4 \mu \mathrm{m}$ formalin-fixed paraffin-embedded sections of MTC specimens confirming the expression of miRNAs in neoplastic cells for only ten miRNAs. In situ hybridisation shows the expression of miR-7, miR-200b and

given at the end of this article). These capabilities are specifically involved in the metastatic process. Using the intersections of two or more miRNA target databases, we obtained 1159 mRNA targets as potential downstream effectors of this subset of miRNAs. Many of these mRNAs have been well recognised as molecular linkers in the maintenance of cytomorphology, cell adhesion, cell movement and ECM remodelling. As a result, it is conceivable that this ten miRNA gene signature may contribute to the regulation of important aspects of the MTC metastatic process through the regulation of genes and biological functions implicated in cancer progression. Gene Set Enrichment and Pathway Analysis identified potential target mRNAs involved in several and important gene pathways that may be linked to tumour invasion, metastasis and progression (Supplementary Figure 2A and B). TGF $\beta$ pathway is one of the most important signals regulated by the miRNA target population.
miR-373, confined to tumour cells (arrows) in three different MTC cases (panels A-C-E). Negative controls for each tumour are also reported (panels B-D-F). The in situ hybridisation is a quantitative but also an essential qualitative technique, which allows the exact cellular localization for each miRNA identified. Figure 3 also shows the expression of $m i R-7$ and miR-200c in two different cases of C-cell hyperplasia (panels $\mathrm{G}$ and $\mathrm{H}$ ).

\section{miR-200 and cell phenotype of MTC}

Members of the miR-200 family have been previously identified as playing a key role in tumour progression through the regulation of the EMT process (Mongroo \& Rustgi 2010). This gene family, which exists as two genome clusters (Supplementary Figure 3, see section on supplementary data given at the end of this article), was among those miRNAs significantly repressed in MTC metastasis, suggesting an equivalent role in this tumour type. In order to address this possibility, we showed that members of the miR-200 family prevent EMT by regulating E-cadherin expression (Fig. $4 \mathrm{~A}$ and $\mathrm{B}$ ) through the direct targeting of ZEB1 and ZEB2 (Fig. 5A and C), but not that of other EMT markers such as SNAI1, SNAI2 or TWIST (TWIST1) (data not shown). Furthermore, downregulation of the miR-200 family in MTC cell lines, which express endogenous levels of these miRNAs, induced EMT.

Published by Bioscientifica Ltd 
B
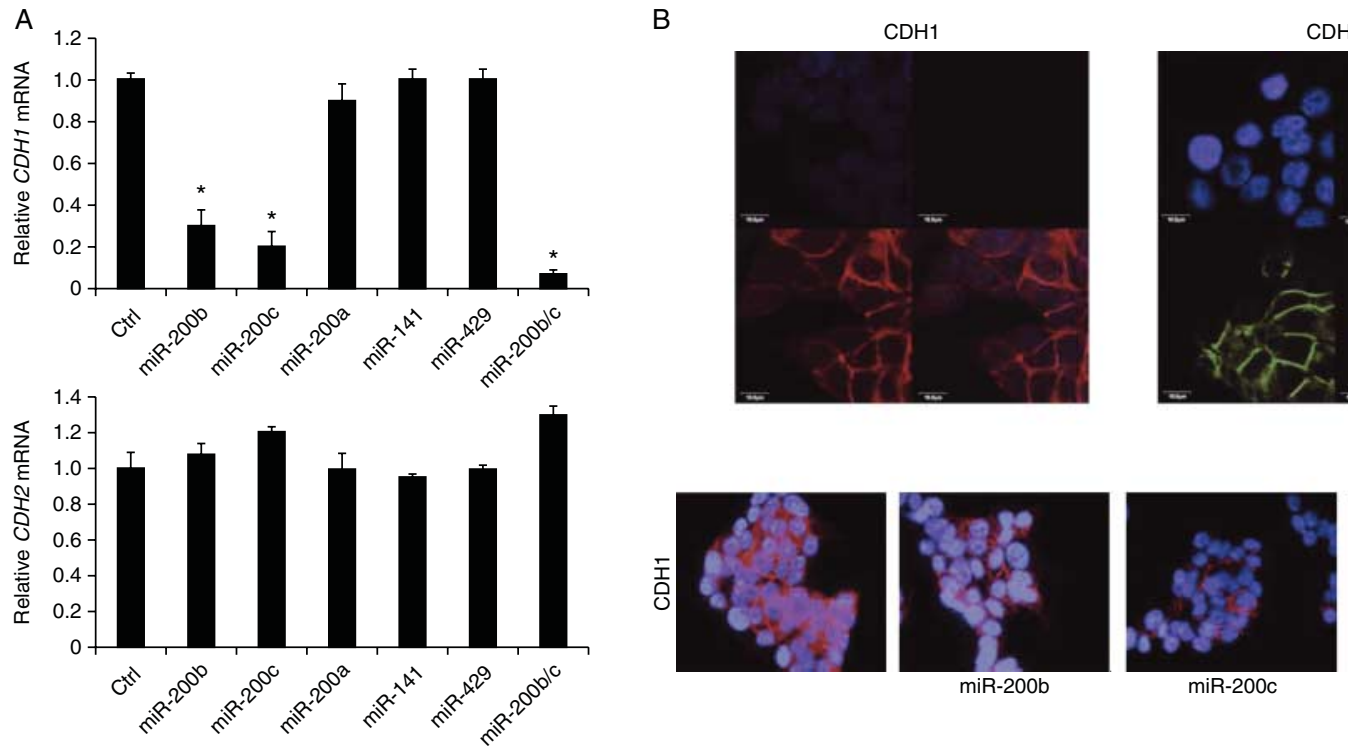

miR-200c

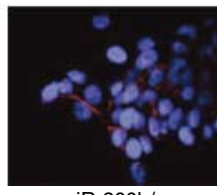

$\mathrm{miR}-200 \mathrm{~b} / \mathrm{c}$

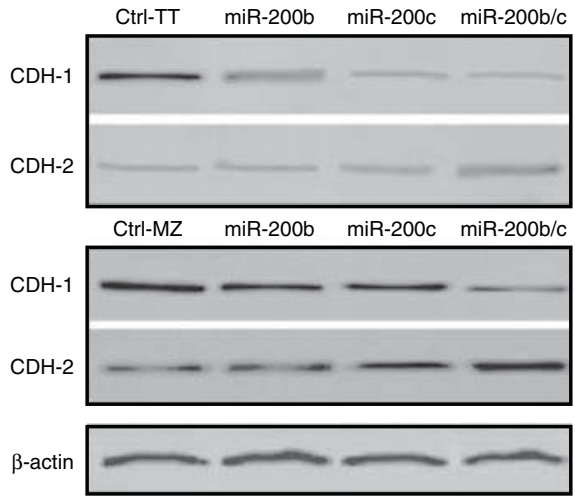

Figure 4

Functional analyses with the antagomirs for miR-200b, showing that members of this family are able to significantly regulate the expression of E-cadherin and slightly affect the expression of N-cadherin in MTC cell lines (A). Quantitative real-time PCR and western blotting analyses showed that E-cadherin (CDH1) was significantly regulated by miR-200b and $-200 \mathrm{c}(\mathrm{A})$. There was an additive effect

In fact, we observed concurrent down-regulation of E-cadherin expression with up-regulation of vimentin, TGF $\beta-1$ and TGF $\beta-2$ (Fig. 5B and C), thus increasing the invasion potential of MTC tumour cells. Interestingly, $Z E B 1$ and $Z E B 2$ expression is similarly regulated in transfected MTC and anaplastic thyroid carcinoma cell lines, suggesting the important role of these genes in tumour aggressiveness (Supplementary Figure 4, see section on supplementary data given at the end of this article). These results strongly suggest an essential role for the miR-200 family in repressing EMT and cancer progression in MTC. Changes in mRNA abundance were confirmed by qRT-PCR analysis, and western blot analysis clearly demonstrated the effect of $m i R-200$ on the protein expression of these tumour markers (Figs 4A and 5A, B and of the two identified miR-200b and -200c on the regulation of E-cadherin expression (A). Asterisks indicate statistical significance. Confocal microscopy confirmed the presence of both E-cadherin $(\mathrm{CDH} 1)$ and $\mathrm{N}$-cadherin $(\mathrm{CDH} 2)$ in MTC cell lines and the regulation of E-cadherin expression by miR-200 (B) with an additive effect by miR-200 family members (B).

C). Furthermore, transfected TT (Fig. 5D) and MZ-CRC-1 (Fig. 5G) MTC cells with miR-200 showed a clear difference in cell phenotype, with cells acquiring a typical spindle shape (Fig. 5D and G) and a loss of cell adhesion (Supplementary Figure 5). The EMT phenomenon with cells with spindle-mesenchymal phenotypes is often visible in metastatic MTCs showing an aggressive behaviour (Supplementary Figure 6). Using an in vitro invasion assay, the miRNA-200 transfected MTC cells showed a significant increase in invasion compared with the controls (Fig. 5E and $\mathrm{H}$ ), with no evident effect on cell proliferation (Fig. 5F and I). To support our cellular data, by IHC assay, we stained our discovery data set and several primary and metastatic tumours (validation data set), confirming the higher expression of vimentin (Fig. 6A and B), 
A
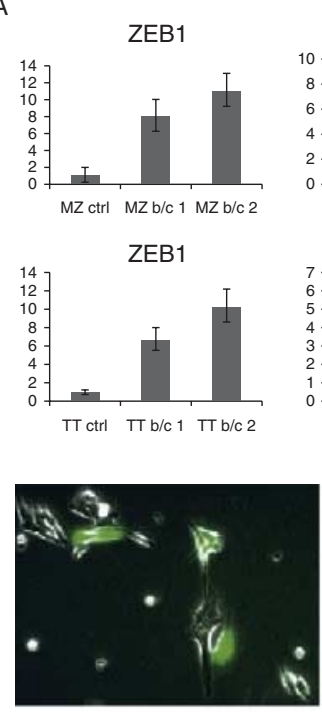

G

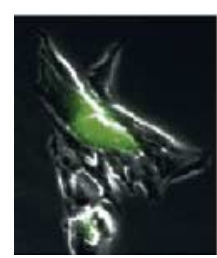

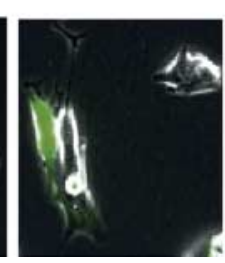

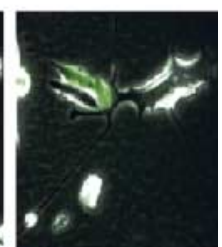

B
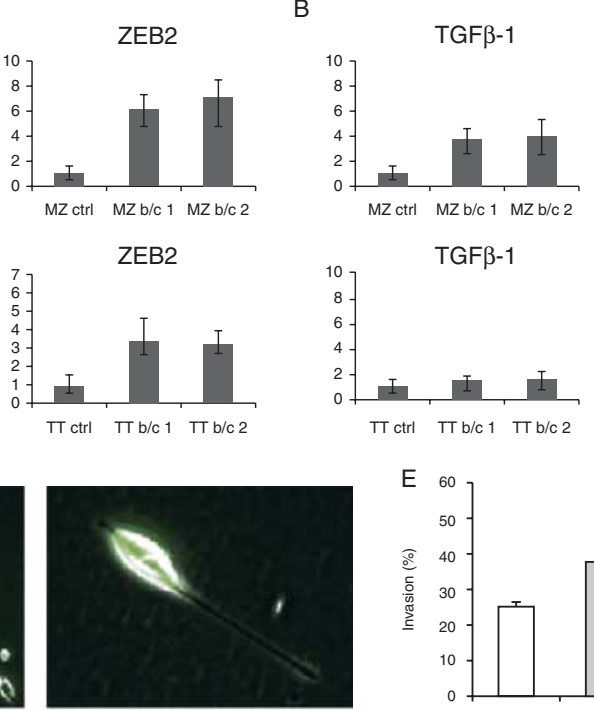

TGF $\beta-1$
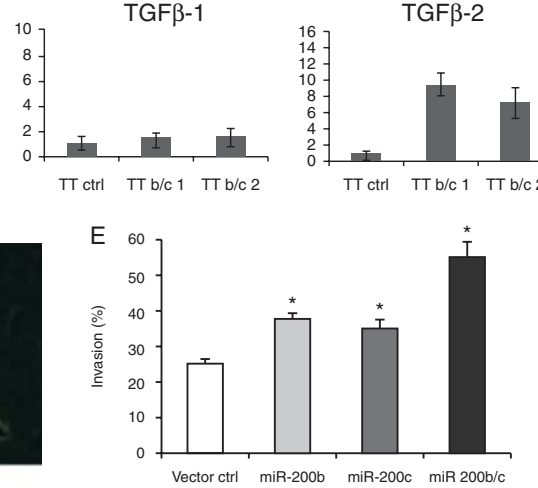

$\mathrm{H}$

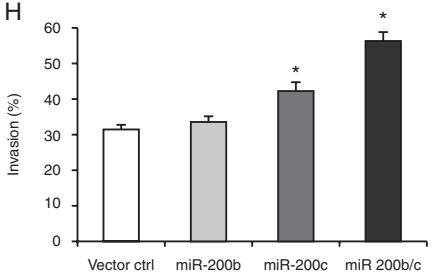

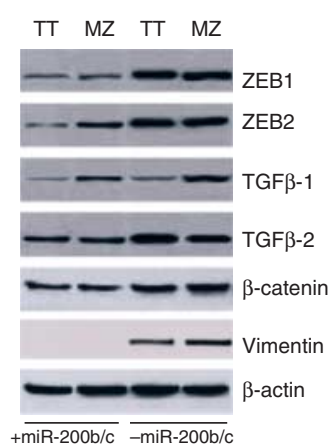
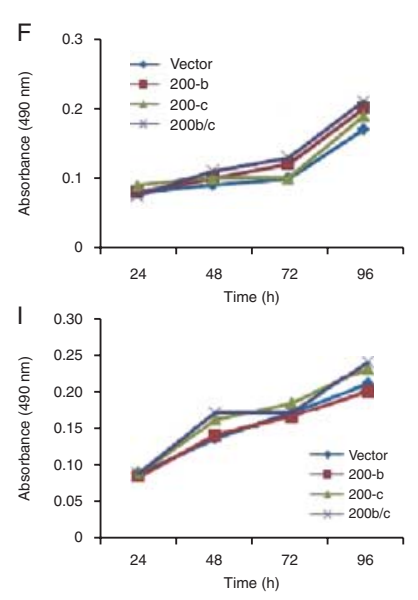

Figure 5

MiR-200 regulates the epithelial to mesenchymal transition and the metastatic features of medullary thyroid carcinoma cells. MiR-200 modulates E-cadherin transcriptional repressors ZEB1 and ZEB2 in MTC cell lines (A and C). MiR-200 significantly affects the expression of TGF $\beta-1$ and TGF $\beta-2$ (B and C). Moreover, down-regulation of $m i R-200$ in MTC cells led to an increase in vimentin, a well-established mesenchymal marker (C),

lower expression of E-cadherin (Fig. 6C and D) and higher expression of TGF $\beta-1$ (Fig. 6E) and TGF $\beta-2$ (Fig. 6F) in metastatic tumours. Of note, the significant increase in the expression of TGF $\beta-2$ in metastatic tumour samples $(P=0.0062$, Table 1$)$ and its inverse correlation with $m i R-200$ expression ( $P=0.005665$, Supplementary Figure 7$)$, which provides a strong support for a crucial role played by the miR-200/TGF $\beta$ axis during MTC progression.

\section{Discussion}

For nearly all tumour types, metastases correlate with poor prognosis and outcome in cancer patients, and they are ultimately responsible for most cancer-related deaths (Larimore \& Wells 1997). Metastases arise following the spread of cancer cells to distant organs; therefore, the identification of mechanisms that control the progression of this process is critical for discovering a cancer cure. Genomic studies on thyroid cancers of follicular origin whereas $\beta$-catenin expression was not affected (C). MiR-200 affects cell shape ( $D$ and $G)$, migration and invasion ( $E$ and $H$ ) but not proliferation (F and I) in MTC TT and MZ-CRC-1 cell lines, respectively. Neoplastic cells undergo a shift from an epithelial to a mesenchymal phenotype through the regulation of important EMT signals.

have identified several deregulated miRNA genes that are gaining potential utility as biomarkers, but their specific role in metastasis is less clear (Nikiforova et al. 2008, Pallante et al. 2010, de la Chapelle \& Jazdzewski 2011, Dettmer et al. 2013, Jacques et al. 2013, Swierniak et al. 2013). To date, few studies have reported deregulation of few miRNAs in thyroid cancer of parafollicular origin associated with prognosis (Abraham et al. 2011). Different reports demonstrated the role of $m i R-200$ in thyroid tumours of follicular origin and in undifferentiated histotypes (Braun et al. 2010). Thus, the role of miRNAs in thyroid cancer metastases remains largely unknown. To identify potential new biomarkers involved in the pathobiology and metastasis of MTC, we performed miRNA profiling in paired primary and metastatic tumour samples. Our combined data set, which included arraybased identification followed by qRT-PCR and in situ confirmation, uncovered ten miRNAs with significant deregulation associated with metastatic MTC tumours.

Published by Bioscientifica Ltd 

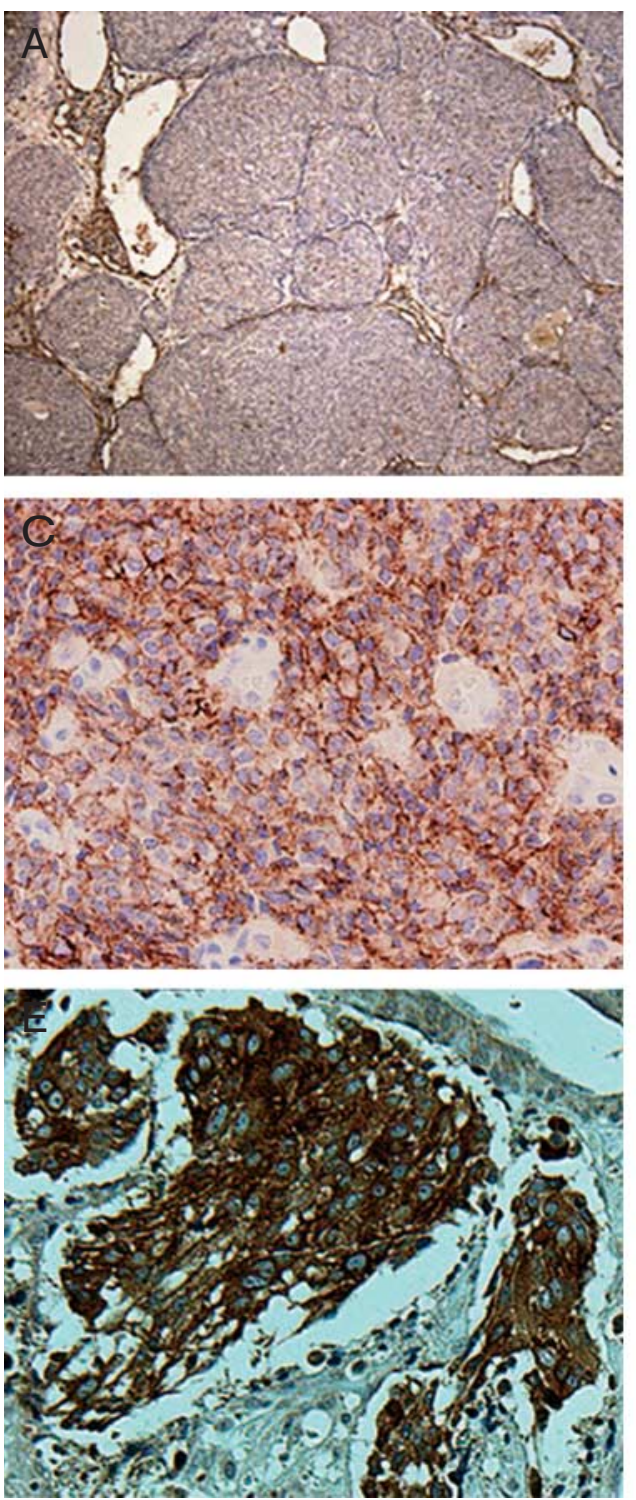

\section{Figure 6}

Immunostaining for vimentin in a metastatic MTC tumour at two different magnifications (panels A and B). In a consecutive series of primary and metastatic MTC samples (the validation data set), the expression of vimentin was significantly higher in the metastatic tumour sites $(P=0.004567)$. The expression of $\mathrm{E}$-cadherin in a paired primary and metastatic MTC tumour (panels C and D respectively); this marker was expressed in both tumour components but with a trend of loss of expression in the metastatic component. The same trend for E-cadherin

Therefore, by different molecular approaches that include cell-specific in situ hybridisation, we have demonstrated the MTC-specific expression of miRNAs, suggesting a role for this class of molecules in tumour progression. Noteworthy, we demonstrated the expression of specific miRNAs also in c-cell hyperplasia, suggesting a potential role of these miRNAs during MTC tumourigenesis as well.
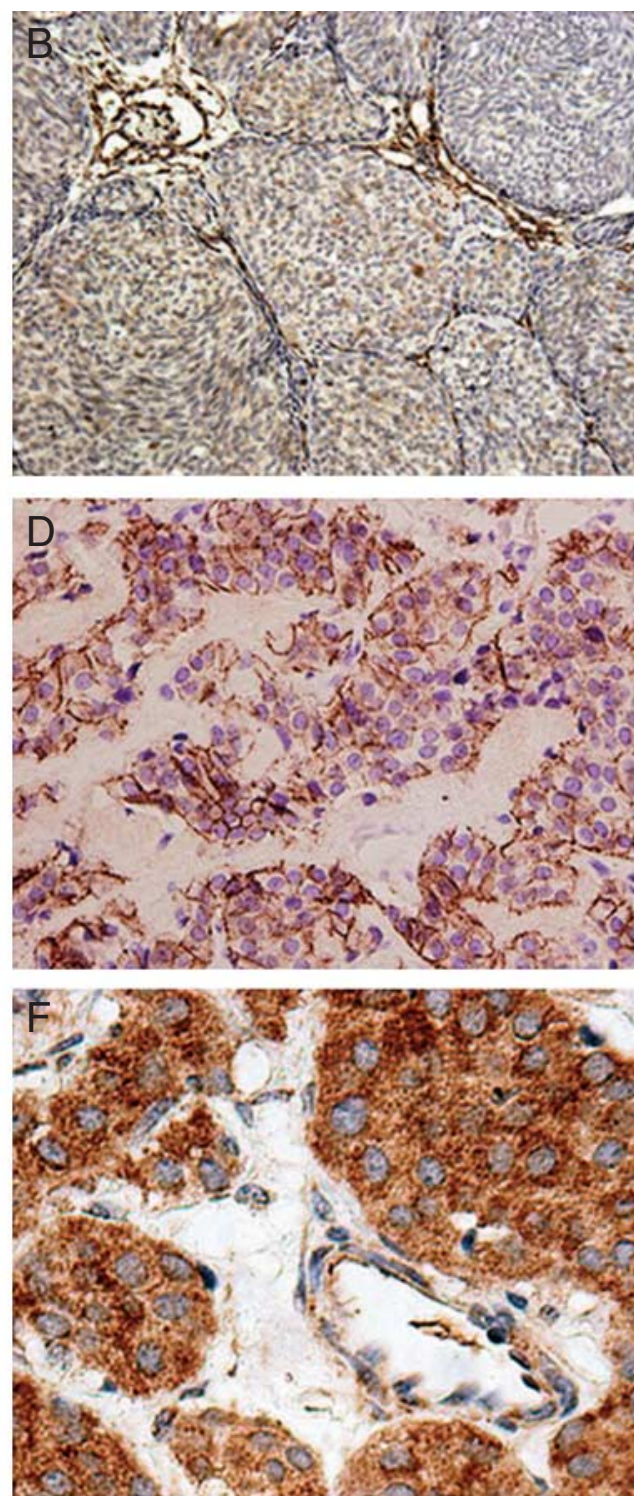

was seen in the validation MTC data set. TGF $\beta$-1 (panel E) and TGF $\beta-2$ (panel F) protein expression in the validation data set analysed showed a higher expression of both markers in metastatic tumour sites, particularly the TGF $\beta$-2 protein $(P=0.0062)$. Of note, the inverse correlation between the expression of $m i R-200$ and TGF $\beta-2$ in the discovery $(P=0.046788)$ and in the validation MTC tumour data sets $(P=0.005665$, supplementary file) indirectly confirming the regulation of TGF $\beta$ pathway by miR-200.

Among the miRNAs identified, we were drawn to $m i R-200$ because of its previously reported role in EMT in a variety of tumours (Burk et al. 2008, Korpal \& Kang 2008), including thyroid tumours of follicular origin (Braun \& Hüttelmaier 2011). By examining specific target gene expressions and functions related to metastasis through genetic assays on human tumour samples and in vitro

Published by Bioscientifica Ltd. 
Table 1 Tumour growth factor $\beta-1$ and -2 protein expression analysed by immunohistochemistry in primary and metastatic medullary thyroid carcinomas demonstrated a significant association between high expression of TGF $\beta-2$ and metastatic tumours. The same subset of tumours with high expression of TGF $\beta-2$ showed a significant lower expression of miR-200b/c (supplementary files)

\begin{tabular}{|c|c|c|c|}
\hline & $\begin{array}{c}\text { Primary } \\
\text { tumours N }\end{array}$ & $\begin{array}{l}\text { Metastatic } \\
\text { tumours N }\end{array}$ & $P$ value \\
\hline \multicolumn{4}{|l|}{ TGF $\beta-1^{a}$} \\
\hline IHC (low) & 14 & 12 & 0.2975 \\
\hline IHC (high) & 13 & 21 & \\
\hline \multicolumn{4}{|l|}{ TGF $\beta-2^{\mathrm{b}}$} \\
\hline IHC (low) & 19 & 9 & 0.0062 \\
\hline IHC (high) & 12 & 25 & \\
\hline
\end{tabular}

TGF $\beta$ protein 1 and 2 immunostainings on two data sets of medullary thyroid carcinomas. For pair-wise comparisons, immunostaining data were collapsed in low $(0-2+)$ and high scores $(3+)$ based on staining intensity and tumour cellularity.

${ }^{a}$ For TGF $\beta-1$ protein expression analysis, five tumours were not available for IHC.

${ }^{\mathrm{b}} \mathrm{TGF} \beta-2$ staining intensity in primary and metastatic medullary thyroid carcinomas was significantly inversely correlated with miRNA-200b expression ( $P=0.005665$, ANOVA test on linear regression models).

experiments on MTC cell lines, we were able to confirm the important role that those genes have in tumour progression. Although almost all members of the $m i R-200$ family (miR-200a-b-c, miR-141, and miR-429) have been shown to play a variety of crucial roles in metastatic processes (Sossey-Alaoui et al. 2009), miR-200b and $\mathrm{miR}-200 \mathrm{c}$ have been directly correlated with the regulation of E-cadherin and vimentin expression in epithelial cells (Ahmad et al. 2011), EMT and cell adhesion, while controlling stem cell-like properties in various types of tumours (Bracken et al. 2008, Gregory et al. 2008). Moreover, these two miRNAs have been shown to be markers of aggressiveness and chemoresistance in several tumours. The connection between miR-200 family members and EMT has revealed a complex gene-regulatory network involved in tumour progression, involving E-box binding transcription factors such as ZEB1/EF1, ZEB2/SIP1, SNAI1, SNAI2 and TWIST1 (Korpal et al. 2008, Park et al. 2008, Kong et al. 2009). A common mechanism for these transcription factors is to repress E-cadherin expression through their direct binding to the E-box motifs within the promoter of E-cadherin, converting epithelial cells into mesenchymal or mesenchymal-like cells that are capable of acquiring an invasive phenotype (Peinado et al. 2007, Thiery et al. 2009). An EMT-like process occurs during the course of tumour progression (Gröger et al. 2012) when adherens junctions become partially dissociated and when epithelial cells switch from a collective invasion pattern to a detached and disseminated cell migration method (Wells et al. 2011). By array analysis, we found $m i R-200 b$ and $m i R-200 c$ to be significantly down-regulated in MTC metastases, consistent with reports showing a deregulation of this miRNA class during the metastatic process. Deregulation of other members of the miR-200 family, even if not statistically significant (data not shown), was also associated with metastatic tumours, thus suggesting a potential common regulatory network controlled by this miRNA family.

To derive mechanistic insight into the role of $m i R-200$ in MTC, we examined the available cell culture models. Both human TT and MZ-CRC-1 MTC cell lines endogenously express miR-200, suggesting that these cancer cells, despite their embryogenetic origin, preserve an epithelial phenotype. Therefore, we treated the MTC cell lines with antagomirs for miR-200b and miR-200c and found that these cells progressively lost the ability to express E-cadherin, acquired the ability to express vimentin and showed a slight increase in N-cadherin levels. Loss of E-cadherin has been widely demonstrated to be associated with metastasis in several neoplastic conditions (Rodriguez et al. 2012), although the reduction of E-cadherin by itself seems not to confer full metastatic capabilities, at least in differentiated follicular thyroid cancers (Calì et al. 2007). Previous studies have linked miR-200 expression with an epithelial phenotype and the ZEB family. Accordingly, expression of the miR-200 family, particularly $m i R-200 b$ and $m i R-200 c$, has been found in epithelial tissues (Kong et al. 2009, De Craene \& Berx 2013) and is negatively correlated with ZEB1 and ZEB2 expression during embryonic development and metastasis (Brabletz $\&$ Brabletz 2010). ZEB family proteins are zinc finger and homeobox domains containing transcription factors. While ZEB proteins mainly function as transcriptional suppressors, they are able to activate transcription, dependent on the DNA context and cell type (Postigo 2003). One of the targets suppressed by ZEB proteins is E-cadherin. Down-regulation of E-cadherin is one of the hallmarks of the EMT, a critical feature of normal embryonic development, which is also utilised by malignant epithelial tumours to spread beyond their origin (Sánchez-Tilló et al. 2012). We demonstrated the functional involvement of miR-200 in EMT and tumour invasion in MTC as well as direct regulation of ZEB1 and ZEB2 by $m i R-200$. In our study, we identified the $m i R-200$ family as suppressors of EMT through direct targeting of ZEB1 and ZEB2, which are well-known transcriptional repressors of E-cadherin. A noteworthy knockdown of

Published by Bioscientifica Ltd. 
miR-200 with antagomirs in the MTC cell lines resulted in ZEB1 expression similar to that found in anaplastic thyroid cancer cell lines. Importantly, we found that miR-200 regulates the expression of additional 'metastatic' markers, such as TGF $\beta-1$ and TGF $\beta-2$, which have been previously shown to be associated with metastatic features in several tumours (Jakowlew 2006, Katsuno et al. 2013). The TGF $\beta$ pathway is involved in several processes, including cell proliferation, differentiation, migration and apoptosis (Elliott \& Blobe 2005). Importantly, recent studies addressed an important role played by TGF $\beta$ in mediating stromal-epithelial interactions during cancer progression (Stover et al. 2007, Tait et al. 2007, Bierie et al. 2008). Interestingly, two recent papers reported that the abnormal activation of TGF $\beta$ signalling induces cancer progression in BRAF-mutant thyroid carcinomas (Eloy et al. 2012) and higher levels of TGF $3-2$ expression in the sera of metastatic MTC patients (Broutin et al. 2011).

In our study, we also found of particular interest the concurrent presence of the two cadherins ( $\mathrm{E}$ and $\mathrm{N}$ ) in both MTC cell lines, which in some ways resemble the neurocrest origin and epithelial differentiation of these tumour cells. Metastasis in MTC may be caused by the reversible shifting status of these cells that undergo a change from an epithelial to a mesenchymal 'status,' perhaps acquiring stem cell-like features due to the presence of cancer stem cells in MTC, as recently reported (Zhu et al. 2010), which could be regulated in part by miR-200 expression.

Several tumour cells, including MTC, are known to reactivate embryonic programs, such as EMT, to obtain a selective advantage, such as enhanced invasiveness (Sánchez-Tilló et al. 2012). As EMT is tightly linked to invasive carcinomas, molecular regulators of this process may serve as key points for therapeutic intervention. Furthermore, in this study, we demonstrated a robust and reliable miRNA signature and target-regulated genes associated with human metastatic MTCs.

\section{miRNAs down-regulated in metastatic tumours}

We found three additional miRNAs, miR-7, miR-10a and $m i R-29 c$, which were down-regulated in metastatic tumours compared with the parental primaries. While we did not perform more detailed mechanistic studies on these miRNAs, all have previously documented roles in tumourigenesis. miR-7 has been recently demonstrated to regulate the expression of epidermal growth factor receptor (EGFR) in several cell systems (Webster et al. 2009, Giles et al. 2011). Notably, EGFR has been found to be overexpressed in various types of thyroid carcinomas, including MTC, and to partially contribute to the regulation of the RET proto-oncogene (Gujral et al. 2008, Santarpia et al. 2009), a driver of thyroid tumourigenesis (Koch et al. 2001). The second down-regulated gene, miR-10a, which is located between the HOXB4 and HOXB5 genes on chromosome 17q21, has been demonstrated to be involved in the regulation of HOXD4 in breast cancer cells (Tan et al. 2009) and in acute and chronic myeloid leukaemia (Agirre et al. 2008, Garzon et al. 2008). Moreover, this miRNA shows high-sequence homology with miR-10b, which has been shown to be an important regulator of breast cancer progression. Deregulation of $m i R-10 a$ has been associated with metastases in other types of carcinomas (Veerla et al. 2009). Finally, miR-29c, together with other $m i R-29$ family members (i.e. $m i R-29 a$ and $m i R-29 b$ ), up-regulates p53 levels and induces apoptosis in a p53-dependent manner. The miR-29 family members also directly suppress $\mathrm{p} 85$ alpha (the regulatory subunit of PI3 kinase) and CDC42 (a Rho family GTPase), both of which negatively regulate p53 (Park et al. 2009) that has been shown to play an important role in cell proliferation and apoptosis in MTC. MiR-29 targets expression of diverse proteins like collagens, and transcription factors, which may take part in abnormal migration, invasion or proliferation of cells and may favour development of cancer (Sengupta et al. 2008, Schmitt et al. 2013). Furthermore, members of the miR-29 family can modulate the ECM by targeting tenascins and can be activated by interferon signalling, which suggests a role in the immune system and in the tumour microenvironment (Schmitt et al. 2013).

\section{miRNAs up-regulated in metastatic MTC tumours}

Five miRNAs - including miR-130a, miR-138, miR-193a, $m i R-373$ and $m i R-498$ - were found to be up-regulated in metastatic tumours. Therefore, the expectation is that there would be a coordinated down-regulation of their mRNA targets, which could include tumour suppressor genes as well as genes that promote apoptosis or cell migration or inhibit angiogenesis. MiR-130a was found to regulate angiogenesis by modulating the expression of the anti-angiogenic homeobox genes GAX (MEOX2) and HOXA5 (Chen \& Gorski 2008); miR-130a was also found to be deregulated in prostate tumours (Boll et al. 2013). Deregulation of $m i R-138$ has been shown to be associated with the overexpression of human telomerase RT protein in human anaplastic thyroid carcinoma cell lines (Mitomo et al. 2008) and to suppress invasion, promoting apoptosis

Published by Bioscientifica Ltd 
in head and neck squamous cell carcinoma cell lines (Liu et al. 2009). MiR-193 affects the activation of the caspase cascade. Putative targets of this miRNA include genes encoding death receptors, caspases and other apoptosis-related genes (Santarpia et al. 2010). Deregulation of $m i R-373$ has been shown to promote invasion and metastases in human breast cancer cell lines (Huang et al. 2008) and to behave as a tumour suppressor in oestrogen receptor-negative breast tumours (Keklikoglou et al. 2012). It has also associated with other types of tumours, such as prostate and ovarian cancers (Santarpia et al. 2010). MiR-498 has been demonstrated to correlate with disease-free survival in patients with stage II colon cancer (Schepeler et al. 2008).

Of note, our data identify mRNA targets which are involved in important signalling pathways coupled to metastasis in MTC (Supplementary Figure $2 \mathrm{~A}$ and $\mathrm{B}$ ), such as the TGF- $\beta$, PI3K/Akt-mTOR, Wnt/ $\beta$-catenin and NOTCH pathways. Some of these signalling pathways have already been shown to be involved in MTC progression (Cook et al. 2010), while others certainly deserve further investigation. Taken together, our results identify a group of metastasis-related gene targets and signals whose expression could be regulated by this subset of miRNAs. Several of these miRNAs have been shown to be associated with many aspects of the metastatic process in several types of cancers, thereby supporting an important regulatory effect of this miRNA signature in MTC metastasis and progression. Our data provide potential mechanistic insight into the role of miRNAs in regulating metastatic capabilities, such as cell adhesion, migration and invasion, maintenance of differentiation, ECM modelling and interactions, and the modulation of other important oncogenic signals, some of which have been previously reported to be involved in MTC progression. Because the $m i R-200$ family functions as putative tumour suppressors and represents biomarkers for aggressive thyroid cancers, the restoration of $m i R-200$ expression may have therapeutic implications for the treatment of metastatic and drug-resistant MTC tumours.

In conclusion, this study provides a leap forward in our understanding of metastatic MTC because it connects the expression levels of ten miRNAs and their associated biological functions and pathways with metastatic MTC. Further studies of this miRNA signature are required to fully understand the role of each miRNA in MTC metastasis. In the near future, some of these miRNAs might be useful as prognostic markers of MTC, providing an important avenue for developing new diagnostic and therapeutic targets for the treatment of metastatic MTC.

\section{Supplementary data}

This is linked to the online version of the paper at http://dx.doi.org/10.1530/ ERC-13-0357.

\section{Declaration of interest}

The authors declare that there is no conflict of interest that could be perceived as prejudicing the impartiality of the research reported.

\section{Funding}

This research is supported in part by the National Institutes of Health through MD Anderson's Cancer Center Support Grant CA016672 for work performed in the Institutional Bioinformatics Shared Resource, Genomics, High Resolution Electron Microscopy, Flow Cytometry and Cellular Imaging Core Facilities.

\section{Acknowledgements}

The authors would like to thank the American Thyroid Association (ATA) for a ThyCa Grant (to L Santarpia) and the Kosberg and Carrozza-Pollicino Foundations (R F Gagel and L Santarpia) for primary support of this research. In addition, they also thank Dr Wang for kindly providing the miRNA-200 expression vectors as well as D Bell, S C Huang, $\mathrm{K} \mathrm{T} \mathrm{Vu} \mathrm{and}$ $Y$ Hayashi for general technical assistance, $\operatorname{Dr} G$ Bianchini for statistical analysis and Dr S Rossi, Dr L Zhang and H Yao for bioinformatic support.

\section{References}

Abraham D, Jackson N, Gundara JS, Zhao J, Gill AJ, Delbridge L, Robinson RG \& Sidhu SB 2011 MicroRNA profiling of sporadic and hereditary medullary thyroid cancer identifies predictors of nodal metastasis, prognosis, and potential therapeutic targets. Clinical Cancer Research $\mathbf{1 7}$ 4772-4781. (doi:10.1158/1078-0432.CCR-11-0242)

Agirre X, Jiménez-Velasco A, San José-Enériz E, Garate L, Bandrés E, Cordeu L, Aparicio O, Saez B, Navarro G, Vilas-Zornoza A et al. 2008 Down-regulation of hsa-miR-10a in chronic myeloid leukemia CD34 + cells increases USF-mediated cell growth. Molecular Cancer Research 6 1830-1840. (doi:10.1158/1541-7786.MCR-08-0167)

Ahmad A, Aboukameel A, Kong D, Wang Z, Sethi S, Chen W, Sarkar FH \& Raz A 2011 Phosphoglucose isomerase/autocrine motility factor mediates epithelial-mesenchymal transition regulated by miR-200 in breast cancer cells. Cancer Research 71 3400-3409. (doi:10.1158/00085472.CAN-10-0965)

American Thyroid Association Guidelines Task Force. Kloos RT, Eng C, Evans DB, Francis GL, Gagel RF, Gharib H, Moley JF, Pacini F, Ringel MD et al. 2009 Medullary thyroid cancer: management guidelines of the American Thyroid Association. Thyroid 19 565-612. (doi:10.1089/thy. 2008.0403)

Bierie B, Stover DG, Abel TW, Chytill A, Gorska AE, Aakre M, Forrester E, Yang L, Wagner KU \& Moses HL 2008 Transforming growth factor- $\beta$ regulates mammary carcinoma cell survival and interaction with the adjacent microenvironment. Cancer Research 68 1809-1819. (doi:10.1158/0008-5472.CAN-07-5597)

Boll K, Reiche K, Kasack K, Mörbt N, Kretzschmar AK, Tomm JM, Verhaegh G, Schalken J, von Bergen M, Horn F et al. 2013 MiR-130a, miR-203 and miR-205 jointly repress key oncogenic pathways and are downregulated in prostate carcinoma. Oncogene 32 277-285. (doi:10.1038/onc.2012.55)

Brabletz S \& Brabletz T 2010 The ZEB/miR-200 feedback loop - a motor of cellular plasticity in development and cancer? EMBO Reports 11 670-677. (doi:10.1038/embor.2010.117)

Bracken CP, Gregory PA, Kolesnikoff N, Bert AG, Wang J, Shannon MF \& Goodall GJ 2008 A double-negative feedback loop between ZEB1-SIP1

Published by Bioscientifica Ltd 
and the microRNA-200 family regulates epithelial-mesenchymal transition. Cancer Research 68 7846-7854. (doi:10.1158/0008-5472. CAN-08-1942)

Braun J \& Hüttelmaier S 2011 Pathogenic mechanisms of deregulated MicroRNA expression in thyroid carcinomas of follicular origin. Thyroid Research 4 S1. (doi:10.1186/1756-6614-4-S1-S1)

Braun J, Hoang-Vu C, Dralle H \& Hüttelmaier S 2010 Downregulation of microRNAs directs the EMT and invasive potential of anaplastic thyroid carcinomas. Oncogene 29 4237-4244. (doi:10.1038/onc.2010.169)

Broutin S, Ameur N, Lacroix L, Robert T, Petit B, Oumata N, Talbot M, Caillou B, Schlumberger M, Dupuy C et al. 2011 Identification of soluble candidate biomarkers of therapeutic response to sunitinib in medullary thyroid carcinoma in preclinical models. Clinical Cancer Research 17 2044-2054. (doi:10.1158/1078-0432.CCR-10-2041)

Burk U, Schubert J, Wellner U, Schmalhofer O, Vincan E, Spaderna S \& Brabletz T 2008 A reciprocal repression between ZEB1 and members of the miR-200 family promotes EMT and invasion in cancer cells. EMBO Reports 9 582-589. (doi:10.1038/embor.2008.74)

Calì G, Zannini M, Rubini P, Tacchetti C, D'Andrea B, Afuso A, Wintermantel T, Boussadia O, Terracciano D, Silberschmidt D et al. 2007 Conditional inactivation of the E-cadherin gene in thyroid follicular cells affects gland development but does not impair junction formation. Endocrinology 148 2737-2746. (doi:10.1210/en.2006-1344)

de la Chapelle A \& Jazdzewski K 2011 MicroRNAs in thyroid cancer. Journal of Clinical Endocrinology and Metabolism 96 3326-3336. (doi:10.1210/jc.2011-1004)

Chen Y \& Gorski DH 2008 Regulation of angiogenesis through a microRNA (miR-130a) that down-regulates antiangiogenic homeobox genes GAX and HOXA5. Blood 111 1217-1226. (doi:10.1182/blood-2007-07104133)

Cook M, Yu XM \& Chen H 2010 Notch in the development of thyroid C-cells and the treatment of medullary thyroid cancer. American Journal of Translational Research 2 119-125.

De Craene B \& Berx G 2013 Regulatory networks defining EMT during cancer initiation and progression. Nature Reviews. Cancer 2 97-110. (doi:10.1038/nrc3447)

Dettmer MS, Perren A, Moch H, Komminoth P, Nikiforov YE \& Nikiforova MN 2013 Comprehensive microRNA expression profiling identifies novel markers in follicular variant of papillary thyroid carcinoma. Thyroid [in press]. (doi:10.1089/thy.2012.0632)

Elliott RL \& Blobe GC 2005 Role of transforming growth factor $\beta$ in human cancer. Journal of Clinical Oncology 23 2078-2093. (doi:10.1200/JCO. 2005.02.047)

Eloy C, Santos J, Cameselle-Teijeiro J, Soares P \& Sobrinho-Simões M 2012 TGF- $\beta /$ Smad pathway and BRAF mutation play different roles in circumscribed and infiltrative papillary thyroid carcinoma. Virchows Archiv 460 587-600. (doi:10.1007/s00428-012-1234-y)

Eng C, Clayton D, Schuffenecker I, Lenoir G, Cote G, Gagel RF, van Amstel HK, Lips CJ, Nishisho I, Takai SI etal. 1996 The relationship between specific RET proto-oncogene mutations and disease phenotype in multiple endocrine neoplasia type 2 . International RET mutation consortium analysis. Journal of the American Medical Association 276 1575-1579. (doi:10.1001/jama.1996.03540190047028)

Garzon R, Garofalo M, Martelli MP, Briesewitz R, Wang L, FernandezCymering C, Volinia S, Liu CG, Schnittger S, Haferlach T et al. 2008 Distinctive microRNA signature of acute myeloid leukemia bearing cytoplasmic mutated nucleophosmin. PNAS 105 3945-3950. (doi:10.1073/pnas.0800135105)

Giles KM, Barker A, Zhang PM, Epis MR \& Leedman PJ 2011 MicroRNA regulation of growth factor receptor signaling in human cancer cells. Methods in Molecular Biology 676 147-163. (doi:10.1007/978-1-60761863-8_11)

Gregory PA, Bert AG, Paterson EL, Barry SC, Tsykin A, Farshid G, Vadas MA, Khew-Goodall Y \& Goodall GJ 2008 The miR-200 family and miR-205 regulate epithelial to mesenchymal transition by targeting ZEB1 and SIP1. Nature Cell Biology 10 593-601. (doi:10.1038/ncb1722)
Gröger CJ, Grubinger M, Waldhör T, Vierlinger K \& Mikulits W 2012 Meta-analysis of gene expression signatures defining the epithelial to mesenchymal transition during cancer progression. PLOS ONE 7 e51136. (doi:10.1371/journal.pone.0051136)

Gujral TS, van Veelen W, Richardson DS, Myers SM, Meens JA, Acton DS, Duñach M, Elliott BE, Höppener JW \& Mulligan LM 2008 A novel RET kinase- $\beta$-catenin signaling pathway contributes to tumorigenesis in thyroid carcinoma. Cancer Research 68 1338-1346. (doi:10.1158/00085472.CAN-07-6052)

Hofstra RM, Landsvater RM, Ceccherini I, Stulp RP, Stelwagen T, Luo Y, Pasini B, Höppener JW, van Amstel HK, Romeo G et al. 1994 A mutation in the RET proto-oncogene associated with multiple endocrine neoplasia type $2 \mathrm{~B}$ and sporadic medullary thyroid carcinoma. Nature 367 375-376. (doi:10.1038/367375a0)

Hofstra RM, Stelwagen T, Stulp RP, de Jong D, Hulsbeek M, Kamsteeg EJ, van den Berg A, Landsvater RM, Vermey A, Molenaar WM et al. 1996 Extensive mutation scanning of RET in sporadic medullary thyroid carcinoma and of RET and VHL in sporadic pheochromocytoma reveals involvement of these genes in only a minority of cases. Journal of Clinical Endocrinology and Metabolism 81 2881-2884. (doi:10.1210/jc.81.8.2881)

Huang Q, Gumireddy K, Schrier M, le Sage C, Nagel R, Nair S, Egan DA, Li A, Huang G, Klein-Szanto AJ et al. 2008 The microRNAs miR-373 and miR-520c promote tumour invasion and metastasis. Nature Cell Biology 10 202-210. (doi:10.1038/ncb1681)

Iorio MV \& Croce CM 2012 MicroRNA dysregulation in cancer: diagnostics, monitoring and therapeutics. A comprehensive review. EMBO Molecular Medicine 4 143-159. (doi:10.1002/emmm.201100209)

Jacques C, Guillotin D, Fontaine JF, Franc B, Mirebeau-Prunier D, Fleury A, Malthiery Y \& Savagner F 2013 DNA microarray and miRNA analyses reinforce the classification of follicular thyroid tumors. Journal of Clinical Endocrinology and Metabolism 98 E981-E989. (doi:10.1210/jc.2012-4006)

Jakowlew SB 2006 Transforming growth factor- $\beta$ in cancer and metastasis. Cancer Metastasis Reviews 25 435-457. (doi:10.1007/s10555-006-9006-2)

Katsuno Y, Lamouille S \& Derynck R 2013 TGF- $\beta$ signaling and epithelialmesenchymal transition in cancer progression. Current Opinions in Oncology 25 76-84. (doi:10.1097/CCO.0b013e32835b6371)

Keklikoglou I, Koerner C, Schmidt C, Zhang JD, Heckmann D, Shavinskaya A, Allgayer H, Gückel B, Fehm T, Schneeweiss A et al. 2012 MicroRNA$520 / 373$ family functions as a tumor suppressor in estrogen receptor negative breast cancer by targeting NF- $\mathrm{\kappa B}$ and TGF- $\beta$ signaling pathways. Oncogene 31 4150-4163. (doi:10.1038/onc.2011.571)

Koch CA, Huang SC, Moley JF, Azumi N, Chrousos GP, Gagel RF, Zhuang Z, Pacak K \& Vortmeyer AO 2001 Allelic imbalance of the mutant and wild-type RET allele in MEN 2A associated medullary thyroid carcinoma. Oncogene 20 7809-7811. (doi:10.1038/sj.onc.1204991)

Kong D, Li Y, Wang Z, Banerjee S, Ahmad A, Kim HR \& Sarkar FH 2009 miR-200 regulates PDGF- D-mediated epithelial-mesenchymal transition, adhesion, and invasion of prostate cancer cells. Stem Cells $\mathbf{2 7}$ 1712-1721. (doi:10.1002/stem.101)

Korpal M \& Kang Y 2008 The emerging role of miR-200 family of microRNAs in epithelial-mesenchymal transition and cancer metastasis. RNA Biology 5 115-119. (doi:10.4161/rna.5.3.6558)

Korpal M, Lee ES, Hu G \& Kang Y 2008 The miR-200 family inhibits epithelial-mesenchymal transition and cancer cell migration by direct targeting of E-cadherin transcriptional repressors ZEB1 and ZEB2. Journal of Biological Chemistry 283 14910-14914. (doi:10.1074/ jbc.C800074200)

Larimore TC \& Wells SA 1997 Cancer of the endocrine system. In Cancer: Principles and Practice of Oncology, pp 1617-1628, 5th edn. Eds VT DeVita, S Hellman \& SA Rosenberg. Philadelphia, PA: Lippincott-Raven Publishers.

Liu X, Jiang L, Wang A, Yu J, Shi F \& Zhou X 2009 MicroRNA-138 suppresses invasion and promotes apoptosis in head and neck squamous cell carcinoma cell lines. Cancer Letters 286 217-222. (doi:10.1016/j.canlet. 2009.05.030)

Lujambio A \& Lowe SW 2012 The microcosmos of cancer. Nature 482 347-355. (doi:10.1038/nature10888)

Published by Bioscientifica Ltd. 
Mitomo S, Maesawa C, Ogasawara S, Iwaya T, Shibazaki M, Yashima-Abo A, Kotani K, Oikawa H, Sakurai E, Izutsu N et al. 2008 Downregulation of miR-138 is associated with overexpression of human telomerase reverse transcriptase protein in human anaplastic thyroid carcinoma cell lines. Cancer Science 99 280-286. (doi:10.1111/j.1349-7006.2007.00666.x)

Molina JR, Hayashi Y, Stephens C \& Georgescu MM 2010 Invasive glioblastoma cells acquire stemness and increased Akt activation. Neoplasia 12 453-463.

Mongroo PS \& Rustgi AK 2010 The role of the miR-200 family in epithelialmesenchymal transition. Cancer Biology \& Therapy 10 219-222. (doi:10.4161/cbt.10.3.12548)

Nikiforova MN, Tseng GC, Steward D, Diorio D \& Nikiforov E 2008 MicroRNA expression profiling of thyroid tumors: biological significance and diagnostic utility. Journal of Clinical Endocrinology and Metabolism 93 1600-1608. (doi:10.1210/jc.2007-2696)

Pallante P, Visone R, Croce CM \& Fusco A 2010 Deregulation of microRNA expression in follicular-cell-derived human thyroid carcinomas. Endocrine-Related Cancer 17 F91-104. (doi:10.1677/ERC-09-0217)

Park SM, Gaur AB, Lengyel E \& Peter ME 2008 The miR-200 family determines the epithelial phenotype of cancer cells by targeting the E-cadherin repressors ZEB1 and ZEB2. Genes and Development 22 894-907. (doi:10.1101/gad.1640608)

Park SY, Lee JH, Ha M, Nam JW \& Kim VN 2009 miR-29 miRNAs activate p53 by targeting p85 $\alpha$ and CDC42. Nature Structural \& Molecular Biology 16 23-29. (doi:10.1038/nsmb.1533)

Peinado H, Olmeda D \& Cano A 2007 Snail, Zeb and bHLH factors in tumour progression: an alliance against the epithelial phenotype? Nature Reviews. Cancer 7 415-428. (doi:10.1038/nrc2131)

Postigo AA 2003 Opposing functions of ZEB proteins in the regulation of the TGFß/BMP signaling pathway. EMBO Journal 22 2443-2452. (doi:10.1093/emboj/cdg225)

Ritchie ME, Silver J, Oshlack A, Holmes M, Diyagama D, Holloway A \& Smyth GK 2007 A comparison of background correction methods for two-colour microarrays. Bioinformatics 23 2700-2707. (doi:10.1093/ bioinformatics/btm412)

Rodriguez FJ, Lewis-Tuffin LJ \& Anastasiadis PZ 2012 E-cadherin's dark side: possible role in tumor progression. Biochimica et Biophysica Acta $\mathbf{1}$ 23-31. (doi:10.1016/j.bbcan.2012.03.002)

Roubelakis MG, Zotos P, Papachristoudis G, Michalopoulos I, Pappa KI, Anagnou NP \& Kossida S 2009 Human microRNA target analysis and gene ontology clustering by GOmir, a novel stand-alone application. BMC Bioinformatics 10 (Suppl 6) S20. (doi:10.1186/14712105-10-S6-S20)

Sánchez-Tilló E, Liu Y, de Barrios O, Siles L, Fanlo L, Cuatrecasas M, Darling DS, Dean DC, Castells A \& Postigo A 2012 EMT-activating transcription factors in cancer: beyond EMT and tumor invasiveness. Cellular and Molecular Life Sciences 69 3429-3456. (doi:10.1007/s00018-012-1122-2)

Santarpia L \& Bottai G 2013 Inhibition of RET activated pathways: novel strategies for therapeutic intervention in human cancers. Current Pharmaceutical Design 5 864-882. (doi:10.2174/138161213804547240)

Santarpia L, Ye L \& Gagel RF 2009 Beyond RET: potential therapeutic approaches for advanced and metastatic medullary thyroid carcinoma. Journal of Internal Medicine 266 99-113. (doi:10.1111/j.1365-2796.2009. 02112.x)

Santarpia L, Nicoloso M \& Calin GA 2010 MicroRNAs: a complex regulatory network drives the acquisition of malignant cell phenotype. EndocrineRelated Cancer 1 F51-F75. (doi:10.1677/ERC-09-0222)

Santoro M, Carlomagno F, Romano A, Bottaro DP, Dathan NA, Grieco M, Fusco A, Vecchio G, Matoskova B, Kraus MH et al. 1995 Activation of RET as a dominant transforming gene by germline mutations of MEN2A and MEN2B. Science 267 381-383. (doi:10.1126/science. 7824936)
Schepeler T, Reinert JT, Ostenfeld MS, Christensen LL, Silahtaroglu AN, Dyrskjøt L, Wiuf C, Sørensen FJ, Kruhøffer M, Laurberg S et al. 2008 Diagnostic and prognostic microRNAs in stage II colon cancer. Cancer Research 68 6416-6424. (doi:10.1158/0008-5472.CAN-07-6110)

Schmitt MJ, Margue C, Behrmann I \& Kreis S 2013 MiRNA-29: a microRNA family with tumor-suppressing and immune-modulating properties. Current Molecular Medicine 13 572-585. (doi:10.2174/ 1566524011313040009)

Sengupta S, den Boon JA, Chen IH, Newton MA, Stanhope SA, Cheng YJ, Chen CJ, Hildesheim A, Sugden B \& Ahlquist P 2008 MicroRNA 29c is down-regulated in nasopharyngeal carcinomas, up-regulating mRNAs encoding extracellular matrix proteins. PNAS 105 5874-5878. (doi:10.1073/pnas.0801130105)

Sossey-Alaoui K, Bialkowska K \& Plow EF 2009 The miR200 family to microRNAs regulates WAVE3-dependent cancer cell invasion. Journal of Biological Chemistry 284 33019-33029. (doi:10.1074/jbc.M109.034553)

Stover DG, Bierie B \& Moses HL 2007 A delicate balance: TGF- $\beta$ and the tumor microenvironment. Journal of Cellular Biochemistry 101 851-861. (doi:10.1002/jcb.21149)

Swierniak M, Wojcicka A, Czetwertynska M, Stachlewska E, Maciag M, Wiechno W, Gornicka B, Bogdanska M, Koperski L, de la Chapelle A et al. 2013 In-depth characterization of the microRNA transcriptome in normal thyroid and papillary thyroid carcinoma. Journal of Clinical Endocrinology and Metabolism 98 E1401-E1409. (doi:10.1210/jc. 2013-1214)

Tait LR, Pauleyb RJ, Santner SJ, Heppner GH, Heng HH, Rak JW \& Miller FR 2007 Dynamic stromal-epithelial interactions during progression of MCF10DCIS.com xenografts. International Journal of Cancer 120 2127-2134. (doi:10.1002/ijc.22572)

Takahashi M, Ritz J \& Cooper GM 1985 Activation of a novel human transforming gene, ret, by DNA rearrangement. Cell 42 581-588. (doi:10.1016/0092-8674(85)90115-1)

Tan Y, Zhang B, Wu T, Skogerbø G, Zhu X, Guo X, He S \& Chen R 2009 Transcriptional inhibition of Hoxd4 expression by miRNA-10a in human breast cancer cells. BMC Molecular Biology 10 12. (doi:10.1186/ 1471-2199-10-12)

Thiery JP, Acloque H, Huang RY \& Nieto MA 2009 Epithelial-mesenchymal transitions in development and disease. Cell 139 871-890. (doi:10.1016/j.cell.2009.11.007)

Valastyan S \& Weinberg RA 2011 Tumor metastasis: molecular insights and evolving paradigms. Cell 147 275-292. (doi:10.1016/j.cell.2011. 09.024)

Veerla S, Lindgren D, Kvist A, Frigyesi A, Staaf J, Persson H, Liedberg F, Chebil G, Gudjonsson S, Borg A et al. 2009 MiRNA expression in urothelial carcinomas: important roles of miR-10a, miR-222, miR-125b, miR-7 and miR-452 for tumor stage and metastasis, and frequent homozygous losses of miR-31. International Journal of Cancer 124 2236-2242. (doi:10.1002/ijc.24183)

Visone R, Pallante P, Vecchione A, Cirombella R, Ferracin M, Ferraro A, Volinia S, Coluzzi S, Leone V, Borbone E et al. 2007 Specific microRNAs are downregulated in human thyroid anaplastic carcinomas. Oncogene 26 7590-7595. (doi:10.1038/sj.onc.1210564)

Webster RJ, Giles KM, Price KJ, Zhang PM, Mattick JS \& Leedman PJ 2009 Regulation of epidermal growth factor receptor signaling in human cancer cells by microRNA-7. Journal of Biological Chemistry 284 5731-5741. (doi:10.1074/jbc.M804280200)

Wells A, Chao YL, Grahovac J, Wu Q \& Lauffenburger DA 2011 Epithelial and mesenchymal phenotypic switchings modulate cell motility in metastasis. Frontiers in Bioscience 16 815-837. (doi:10.2741/3722)

Zhu W, Hai T, Ye L \& Cote GJ 2010 Medullary thyroid carcinoma cell lines contain a self-renewing CD133 + population that is dependent on ret proto-oncogene activity. Journal of Clinical Endocrinology and Metabolism 95 439-444. (doi:10.1210/jc.2009-1485)

Received in final form 11 September 2013

Accepted 13 September 2013 http://erc.endocrinology-journals.org DOI: 10.1530/ERC-13-0357 (c) 2013 Society for Endocrinology Printed in Great Britain 